\title{
Serological diagnosis of Mycoplasma pneumoniae infection by enzyme immunoassay
}

\author{
SUVI M RÄISÄNEN, JI SUNI, AND PO LEINIKKI \\ From the Municipal Bacteriological Laboratory, Aurora Hospital, 00250 Helsinki 25, Finland
}

SUMMARY Antibodies against Mycoplasma pneumoniae antigen obtained by Tween-ether treatment from purified $M$. pneumoniae were measured by means of enzyme-linked immunosorbent assay (ELISA). Paired sera from 19 patients with pneumonia and from 13 patients with acute pancreatitis with a significant rise in complement fixing antibodies against $M$. pneumoniae were studied. Single sera from healthy 1-year-old children were used as controls. High levels of IgG and IgM class antibodies were seen in sera from patients with pneumonia while most patients with acute pancreatitis and all the children showed low levels of antibodies. The results indicate that ELISA using Tween-ether treated $M$. pneumoniae antigen could be used successfully in the specific laboratory diagnosis of $M$. pneumoniae infection.

The laboratory diagnosis of Mycoplasma pneumoniae infection is usually based on the determination of complement fixing (CF) serum antibodies and on the detection of cold agglutinins. Methods using, for example, immunofluorescence, haemagglutination, and radioimmunoprecipitation have also been reported. ${ }^{1-3}$ The $\mathrm{CF}$ antigen contains surface glycolipids, which are shown to be the most active fraction in inducing CF antibodies, but does not contain protein. ${ }^{4-7}$

The surface glycolipids are, however, not unique to $M$. pneumoniae. For example, Streptococcus $M G$ strain shares glycosyl diglyceride groups with $M$. pneumoniae, and similarities can be found also between $M$. pneumoniae and the cellular components of some host tissues. ${ }^{8-10}$ This raises the possibility of false positive reactions in tests using glycolipid containing antigen. The false positive reactions may be due to some heterogenic CF antibodies against some other microorganism or cellular components in tissues made free by tissue damage. ${ }^{41-14}$ Significant rises of CF serum antibodies have been reported in acute pancreatitis. ${ }^{1415}$ Large amounts of antibodies against $M$. pneumoniae lipid containing antigen have also been detected in children's sera by radioimmunoprecipitation. These antibodies could be blocked efficiently in vitro even by lipids from carrots and parsnips, which supports the view that

\footnotetext{
*Present address: Division of Biomedicine, University of Tampere, Finland.
}

Received for publication 25 November 1979 the test is also measuring some non-specific antibodies. ${ }^{16}$

Recently, M. pneumoniae surface proteins have been isolated and partly characterised. One of these proteins has been reported to be significant to the virulence and infectivity of the $M$. pneumoniae organism. ${ }^{17}$ A method capable of measuring antibodies against such protein containing antigen might not only be more specific but also diagnostically more revealing. We have tried to achieve this by developing an enzyme immunoassay to detect different classes of antibodies against $M$. pneumoniae antigen obtained by Tween-ether treatment.

\section{Material and methods}

\section{SERUM SPECIMENS}

These included paired sera from 19 patients with a clinical diagnosis of pneumonia and with a high titre or a fourfold or greater rise in CF antibodies against $M$. pneumoniae glycolipid antigen. Also included were paired sera from 13 patients with acute pancreatitis and a significant rise in $C F$ antibodies against $M$. pneumoniae in agreement with previous findings. ${ }^{14} 15$ Single sera from 30 healthy 1-year-old infants were used as controls. The CF titres in all of them were low; one-third of the group showed a titre below 8 .

MYCOPLASMA ANTIGEN

$M$. pneumoniae was cultured according to the method of Kenny and Grayston. ${ }^{18}$ After one or two 
passages in PPLO broth, supplemented with $20 \%$ horse serum and $10 \%$ yeast extract, the mycoplasma was cultured on solid agar plates. The agar was then homogenised and transferred into tubes which were incubated for seven to 10 days. Bottles with PPLO broth, $16 \%$ horse serum, $2 \%$ yeast extract, thallium acetate, and glucose were inoculated with these tubes. After seven to 10 days, the suspension was filtered through gauze, and centrifuged at 13500 rpm in a continuous-flow Sorvall rotor, and the pellet was washed with phosphate buffered saline (PBS). The washed pellet was resuspended in PBS. To this suspension Tween 80 was added to give a final concentration of $0.1 \% \mathrm{v} / \mathrm{v}$. One volume of ether was added and, after mixing for 15 minutes at $+4^{\circ} \mathrm{C}$, the water phase was collected. Residual ether was evaporated using $\mathrm{N}_{2}$. The antigen was divided into small fractions and stored at $-20^{\circ} \mathrm{C}$. This antigen containing $2 \mathrm{mg}$ of protein in stock solution (Lowry) per $\mathrm{ml}$ was kindly supplied by Orion Diagnostica (Helsinki, Finland).

Standard $M$. pneumoniae $\mathrm{CF}$ antigen (Orion Diagnostica), consisting of lipids extracted with chloroform and methanol ${ }^{18}$ from cultivated, purified organisms, was used in complement fixation.

\section{BUFFER S}

The buffer solution for diluting the antigen for enzyme immunoassay was a sodium carbonate/ sodium bicarbonate buffer by Delory and King with $4.8 \mathrm{ml}$ of $0.2 \mathrm{M} \mathrm{Na}_{2} \mathrm{CO}_{3}$ and $20.3 \mathrm{ml}$ of $0.2 \mathrm{M} \mathrm{NaHCO}$ and distilled water to $100 \mathrm{ml}$. The $\mathrm{pH}$ of this solution is $\mathbf{9 \cdot 4}$. Serum and conjugate dilutions were made into PBS with $0.2 \%$ Tween 20 and $1 \%$ sheep serum.

\section{CONJUGATES}

Alkaline phosphatase bound antibodies against human IgG and IgM (Orion Diagnostica) were used as conjugates. The anti-human sera were raised in swine. Sigma $104^{\mathrm{R}}$ alkaline phosphatase substrate was used.

THE ASSAY

The enzyme immunoassay was performed, with some modifications, according to the method of Leinikki et al. 1920 The Tween-ether treated antigen was diluted into sodium carbonate/sodium bicarbonate buffer, $\mathrm{pH} 9.4$. The adsorption of the antigen on the walls of nine-well polystyrene cuvettes (Labsystems, Helsinki, Finland) was performed at room temperature overnight. During the experiments all serum incubations were done at $+37^{\circ} \mathrm{C}$ for 2 hours, and the serum samples were diluted $1 / 50$ in duplicate to test the total antibody levels against the Tween-ether treated antigen. The conjugate was incubated overnight at room temperature. The final enzyme- substrate colour reaction was measured with FP-9, a nine-channel photometer (Labsystems), and the results were given as optical density at $405 \mathrm{~nm}$.

\section{Results}

To determine the most suitable working dilution for the antigen, serial dilutions were studied with a known positive and a known negative serum: samples from a patient with $M$. pneumoniae pneumonia and from a 1-year-old healthy child. A stock solution containing $2 \mathrm{mg}$ of protein per $\mathrm{ml}$ of antigen was diluted in two-fold steps from $1 / 200$ to $1 / 3200$. Fresh antigen could be diluted up to $1 / 3200$ with a clear difference between the positive and the negative serum. The optimum antigen level proved to be fairly sharply at the dilution of $1 / 1600$, which corresponds to a protein concentration of approximately $1 \mu \mathrm{g} / \mathrm{ml}$ (Fig. 1). After one to two months' storage at $-20^{\circ} \mathrm{C}$, the antigen seemed to lose some activity, and the working dilution had to be reevaluated.

In order to test the sensitivity of the method, a known positive and negative serum (see above) were diluted in half-logarithm steps from $10^{-1}$ to $10^{-4.5}$. The sera were tested with both anti-IgG and anti-IgM conjugates. In both tests the positive serum gave a slowly falling curve and was markedly different from the negative serum (Figs 2 and 3).

To compare the activities observed in various serum samples against the Tween-ether treated antigen, the specimens were all tested at the same time and the results were given as standard deviation (SD) from the mean optical density value of the control group. In the IgM test, the mean (of 30 single serum specimens from 1-year-old children) was 0.178 optical density units at $405 \mathrm{~nm}$ and the SD was 0.074. In the IgG test, the corresponding values were mean 0.074 and SD 0.040 . There was a distinct difference between the results from patients with acute pancreatitis and $M$. pneumoniae pneumonia. Most patients with a significant rise in complement fixing antibodies against $M$. pneumoniae and with acute pancreatitis could not be regarded as having an acute mycoplasmal infection according to the ELISA results (Figs 4 and 5).

It seems likely that in the Tween 80 -ether treated $M$. pneumoniae antigen proteins carry the antigenic determinants. In this study, no attempt was made to analyse and separate various protein components from $M$. pneumoniae. Further purifications are needed to elucidate the exact structure of the antigen components.

The Tween-ether treated antigen could be used in CF but had low activity. The complement fixing antigen could not, however, be used in ELISA, 


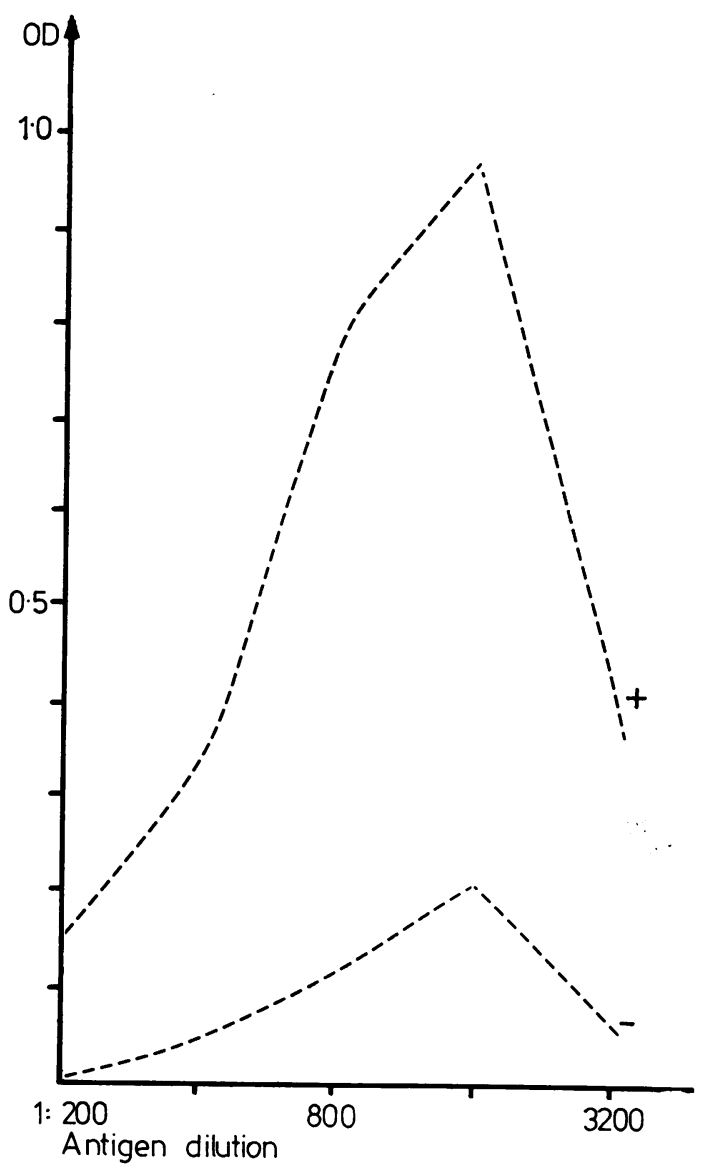

Fig. 1 Serial dilutions of M. pneumoniae Tween-ether treated antigen tested with two known sera diluted 1/10. The positive serum is from a patient with pneumonia and with a high titre up to 4000 in complement fixing antibodies against $\mathrm{M}$. pneumoniae. The negative serum is from a 1-year-old healthy child with a low titre in $C F$ against $\mathrm{M}$. pneumoniae. The ELISA results are given as the value of optical density.
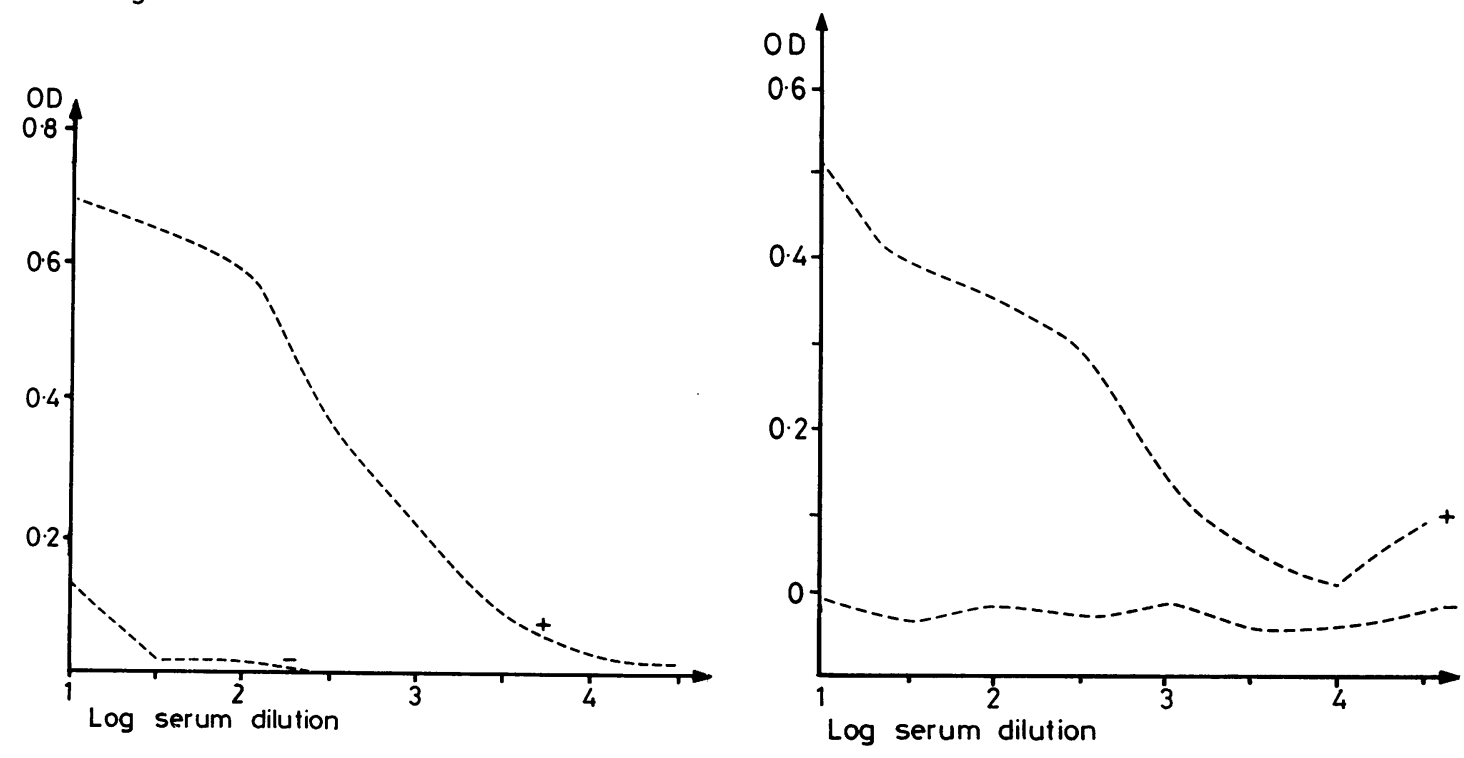

Fig. 2

Fig. 3

Figs 2 and 3 The IgM (Fig. 2) and IgG (Fig. 3) antibody levels of a known positive and negative serum see text) diluted in half-logarithm steps from $10^{-1}$ to $10^{-4.5}$. 


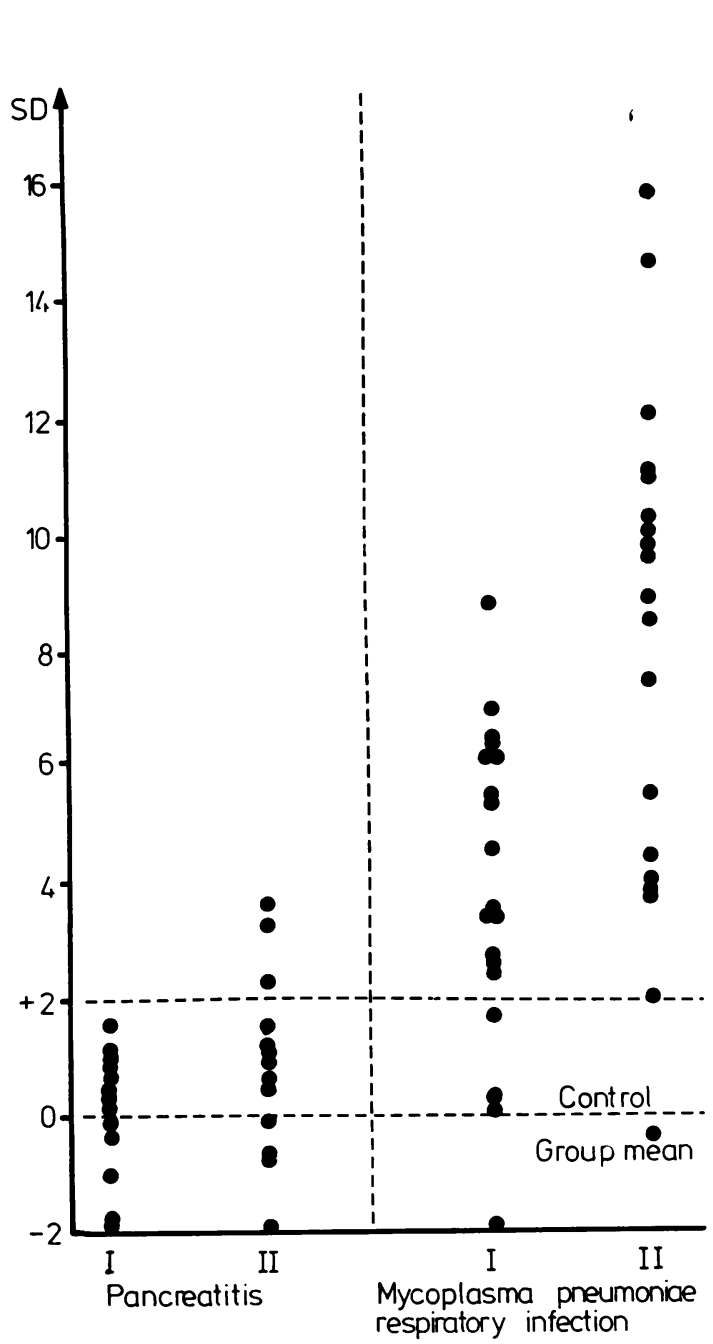

Fig. 4

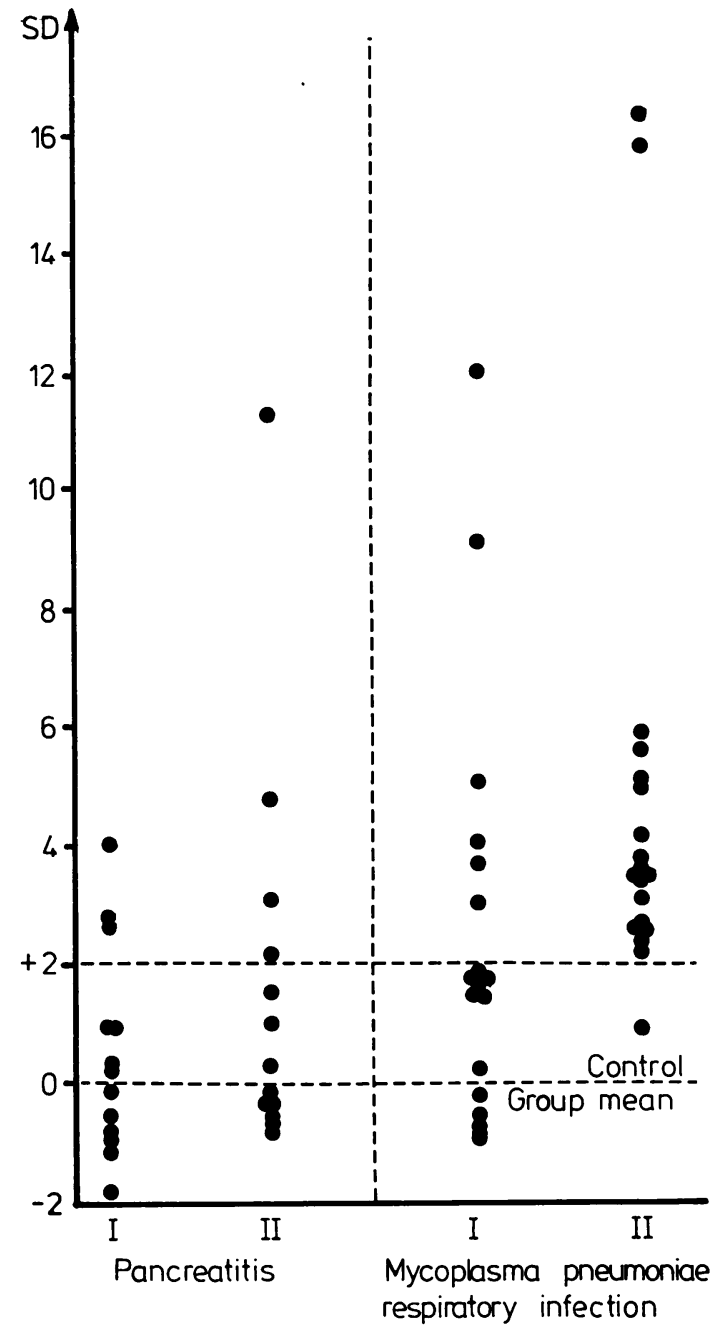

Fig. 5

Figs 4 and 5 Total IgM (Fig. 4) and IgG (Fig. 5) antibody response against M. pneumoniae Tween-ether treated antigen in the patient groups with acute pancreatitis and with pneumonia, and in both groups a diagnostic rise in complement fixing antibodies against $\mathrm{M}$. pneumoniae lipid antigen. The results are given as standard deviations from the mean optical density value of 30 sera from healthy 1-year-old children tested at the same time and with the same antigen.

probably owing to weak adherence to the polystyrene cuvettes.

\section{Discussion}

A significant increase in complement fixing antibodies against the glycolipid antigen of $M$. pneumoniae has been reported in several diseases. In many of them, however, the increase is thought to be nonspecific and due probably to antigenic crossreactions between glycolipids of $M$. pneumoniae and cellular components of damaged tissues or of other infectious agents. ${ }^{1415}$ In spite of the possibility of false positive laboratory diagnoses, the tests using $M$. pneumoniae complement fixing antigen are widely used in clinical microbiology. This is due to the low sensitivity and tedious procedures of other available tests.

Recently, several applications of ELISA have been used successfully in the diagnosis of a variety of viral and bacteriological infections. ${ }^{19-21}$ These tests are both sensitive and specific. By using polystyrene 
plastic sensitised with $M$. pneumoniae Tween 80-ether treated antigen we found that both IgG and IgM antibody levels reacting with this antigen could be measured.

Low ievels of antibody activity against $M$. pneumoniae Tween-ether treated antigen were found in 1-year-old healthy children. This enabled us to use the standard deviation of this material as the reference and to compare other samples with the mean absorbance value of the reference group.

Patients with clinical pneumonia and a previous serodiagnosis of $M$. pneumoniae infection based on complement fixing antibodies showed mostly a rise in both IgM and IgG class antibodies between the first and second serum samples. This somewhat slow antibody formation could be explained by a theory that antibodies against the protein components of $M$. pneumoniae are first produced after a true parasitism on respiratory epithelium has taken place. Patients with acute pancreatitis and a diagnostic rise in antibodies against the glycolipids of $M$. pneumoniae mostly showed values below the level of +2 standard deviations from the control group mean even in the second serum sample. A few sera proved to have significant amounts of antibodies, even in the IgM class, which suggests the presence of a true mycoplasmal infection and would not be surprising because the sera were collected during a period of a $M$. pneumoniae epidemic. These results indicate that ELISA utilising $M$. pneumoniae Tween 80-ether treated antigen containing protein components gives a reliable mean for the diagnosis of $M$. pneumoniae infections.

The application of the IgM antibody assay offers several interesting possibilities. High levels of specific IgM antibodies would enable a diagnosis to be made from a single, early-phase serum sample. It could also be used to distinguish between primary and re-infections and in studies of the clinical differences between these two groups.

This work was supported by the Research and Science Foundations of Orion-yhtymä Oy and Lääke Oy.

\section{References}

${ }^{1}$ Brunner $\mathrm{H}$, Chanock $\mathrm{RM}$. A radioimmunoprecipitation test for detection of Mycoplasma pneumoniae antibody. Proc Soc Exp Biol Med 1973;143:97-105.

${ }^{2}$ Lind K. Preparation of antigen for the indirect fluorescent antibody test in diagnosis of Mycoplasma pneumoniae infection. Acta Path Microbiol Scand Section B 1970; 78:149-52.

${ }^{3}$ Lind K. An indirect haemagglutination test for serum antibodies against Mycoplasma pneumoniae using formalinized, tanned sheep erythrocytes. Acta Path Microbiol Scand 1969;73:459-72.

4 Plackett P, Marmion BP, Shaw EJ, Lemcke RM. Immunochemical analysis of Mycoplasma pneumoniae. 3. Separation and chemical identification of serologically active lipids. Aust J Exp Biol Med Sci 1969;47:171-95.

${ }^{5}$ Razin S, Prescott B, Chanock RM. Immunogenicity of Mycoplasma pneumoniae glycolipids: A novel approach to the production of antisera to membrane lipids. Proc Nat Acad Sci 1970;67:590-7.

${ }^{6}$ Smith PF. Heterogeneity of mycoplasmal lipids. J Inf Dis 1973;127:S 8-11.

${ }^{7}$ Sobeslavsky O, Prescott B, James WD, Chanock RM. Isolation and characterization of fractions of Mycoplasma pneumoniae. II Antigenicity and immunogenicity. $J$ Bacteriol 1966;91:2126-38.

${ }^{8}$ Costea N, Yakulis VJ, Heller P. Inhibition of cold agglutinins (anti-I) by Mycoplasma pneumoniae antigens. Proc Soc Exp Biol Med 1972;139:476-9.

${ }^{9}$ Lemcke RM, Marmion BP, Plackett P. Immunochemical analysis of Mycoplasma pneumoniae. Ann NY Acad Sci 1967;143:691-702.

${ }^{10}$ Rapport MM. Structure and specificity of the lipid haptens of animal cells. J Lipid Res 1961 ;2:25-36.

${ }^{11}$ Alving CR, Joseph KJ, Lindsley HB, Schoenbechler MJ. Immune damage to liposomes containing lipids from Schistosoma mansoni worms. Proc Soc Exp Biol Med 1974;146:458-61.

12 Biberfeld G. Antibodies to brain and other tissues in cases of Mycoplasma pneumoniae infection. Clin Exp Immunol $1971 ; 8: 319-33$.

${ }^{13}$ Freundt EA. Present status of the medical importance of mycoplasmas. Path Microbiol 1974;40:155-87.

${ }^{14}$ Leinikki P, Pantzar P, Tykkä H. Antibody response in patients with acute pancreatitis to Mycoplasma pneumoniae. Scand J Gastroent 1973;8:631-5.

${ }^{15}$ Leinikki P, Pantzar P, Tykkä H. Immunoglobulin M antibody response against Mycoplasma pneumoniae lipid antigen in patients with acute pancreatitis. $J$ Clin Microbiol 1978;8:113-8.

${ }^{16}$ Brunner H, Prescott B, Greenberg H, James WD, Horswood RL, Chanock RM. Unexpectedly high frequency of antibody to Mycoplasma pneumoniae in human sera as measured by sensitive techniques. J Inf Dis $1977 ; 135: 524-30$

${ }^{17} \mathrm{Hu}$ PC, Collier AM, Baseman JB. Surface parasitism by Mycoplasma pneumoniae of respiratory epithelium. $J$ Exp Med 1977;145:1328-43.

${ }^{18}$ Kenny GE, Grayston JT. Eaton pleuropneumonia-like organism (Mycoplasma pneumoniae) complement-fixing antigen. J Immunol 1965;95:19-25.

19 Leinikki P, Pässilä S. Solid phase antibody assay by means of enzyme conjugated to anti-immunoglobulin. $J$ Clin Pathol 1976;29:1116-20.

${ }^{20}$ Leinikki P, Pässilä S. Quantitative semi-automated enzymelinked immunosorbent assay for viral antibodies. $J$ Inf Dis 1977;136:S 294-9.

${ }^{21}$ Voller A, Bidwell DE, Bartlett A. ELISA, a Guide with Abstracts of Microplate Applications. Dynatech Europe publishers, $1979 ; 1-214$.

Requests for reprints to: Dr Suvi M Räisänen, Municipal Bacteriological Laboratory, Aurora Hospital, Helsinki, Finland. 